\title{
PEMANFAATAN KULIT PISANG KEPOK (Musa paradisiaca L.) SEBAGAI SUBTITUSI TEPUNG TERIGU DALAM PENGOLAHAN BISKUIT
}

\author{
Haerul Anwar ${ }^{1)}$, Septiani ${ }^{2}$, Nurhayati ${ }^{3)}$ \\ 1)Program Studi Keperawatan, STIKes Jayakarta, Jakarta Timur, Indonesia \\ 2)Program Studi Teknologi Laboratorium Medis, FST, Universitas Binawan, Jakarta Timur, Indonesia \\ ${ }^{3)}$ Program Studi Pendidikan Matematika, FKIP, Universitas AI Muslim, Aceh, Indonesia \\ Corresponding author: Haerul Anwar \\ E-mail : anwar.haerul90@gmail.com
}

Diterima 19 Maret 2021, Direvisi 05 April 2021, Disetujui 06 April 2021

\begin{abstract}
ABSTRAK
Pisang Kepok (Musa paradisiaca L.) merupakan komoditas holtikultultura yang mudah dibudidayakan dan memiliki nilai produksi yang tinggi di Indonesia. Laju pertumbuhan produksi pisang di Indonesia terus mengalami peningkatan sejak tahun $1998-2015$ yaitu sebesar $0,33 \%$ per tahun, sedangkan kosumsi pisang selama tahun 2002-2015 menunjukkan perkembangan yang berfluktuatif namun cenderung menurun dengan rata-rata sebesar $0,53 \%$ per tahun. Telah dilakukan kegiatan pembuatan biskuit dengan mensubsitusikan tepung kulit pisang kepok dengan tujuan untuk memberdayakan masyarakat Komplek POLRI Jatirangga, Bekasi dalam memanfaatkan limbah kulit pisang kepok menjadi olahan biskuit yang mengandung komposisi gizi yang cukup tinggi dan benilai ekonomis. Pelaksanaan kegiatan ini dilakukan dengan metode penyuluhan yang melibatkan 15 orang peserta. Hasil uji tingkat kesukaan terhadap biskuit menyatakan bahwa daya terima responden secara keseluruluhan adalah memnyukainya, sedangkan hasil uji proksimatnya didaptkan kandungan karbohidrat sebanyak $62,91 \%$, lemak sebanyak $12,23 \%$, protein sebanyak $7,26 \%$, serat pangan sebanyak $51,21 \%$, kalium sebanyak $3272,69 \mathrm{mg} / 100 \mathrm{~g}$, energi sebanyak $390,75 \mathrm{kkal} / 100 \mathrm{~g}$, kadar air sebanyak $8,82 \%$ dan kadar abu sebanyak $8,78 \%$. Kegiatan pengabdian kepada masyarakat ini sangat bermanfaat untuk dilakukan karena masyarakat belum pernah mengolah kulit pisang kepok menjadi tepung yang bisa dimanfatkan menjadi berbagai macam olahan makanan selingan berkhasiat tinggi dan berpotensi dalam mencegah penyakit konstipasi dan hipertensi.
\end{abstract}

Kata kunci: Musa paradisiaca L.; kulit pisang kepok; biskuit.

\begin{abstract}
Kepok Banana (Musa paradisiaca L.) is a horticultural commodity that is easily cultivated and has a high production value in Indonesia. The rate of growth in banana production in Indonesia continues to increase from $1998-2015$, which is equal to $0.33 \%$ per year, while banana consumption during 20022015 shows a fluctuating development but tends to decrease by an average of $0.53 \%$ per year. The activity of making biscuits has been carried out by substituting kepok banana peel flour with the aim of empowering the people of the Jatirangga Police Complex, Bekasi in utilizing the waste of Kepok banana peels into processed biscuits that contain high nutritional composition and economically validity. The implementation of this activity was carried out using the extension method which involved 15 participants. The results of the test level to the biscuit stated that the respondent's overall acceptance was to like it, while the proximate test results were conducted by carbohydrate content of $62.91 \%$, fat as much as $12.23 \%$, protein as much as $7.26 \%$, food fiber as much as $51.21 \%$, potassium as many as $3272.69 \mathrm{mg}$ / $100 \mathrm{~g}$, energy as many as $390.75 \mathrm{Kcal} / 100 \mathrm{~g}$, water content of $8.82 \%$ and ash content was $8.78 \%$. This community service activities are very useful to do because the community has never processed Kepok banana peel into flour that can be widely used into various kinds of high-purpose foods with high efficacy and potentially in preventing constipation and hypertension.
\end{abstract}

Keywords: Musa paradisiaca L.; kepok banana leather; biscuit.

\section{PENDAHULUAN}

Biskuit merupakan salah satu produk pangan olahan yang berbahan dasar tepung terigu yang bisa dikosumsi oleh semua kalangan umur dengan komposisi biskuit yang berbeda sesuai dengan kebutuhannya. Seiring berkembangnya ilmu pengetahuan dan teknologi, pembuatan biskuit terus mengalami inovatif untuk semua aspek, salah satunya adalah mensubsitusikan berbagai jenis olahan 
tepung dengan tepung terigu. Penggunaan tambahan tepung lain pada pembuatan biskuit pasti akan mempengaruhi kuatis biskuit yang dihasilkan. Biskuit yang berkualitas adalah biskuit yang memiliki daya simpan yang lama. Salah satu olahan biskuit dengan komposisi yang kandungan yang kompleks untuk kebutuhan gizi dalam tubuh adalah dengan mensubsitusikan tepung kulit pisang kepok. Pemanfaatan kulit pisang dalam pembuatan biskuit dikarenakan produk biskuit yang dihasilkan akan memiliki umur simpan lebih panjang, mudah dikemas, mudah didistribusikan dan mudah diterima oleh masyarakat, disamping itu juga untuk menciptakan suatu produk makanan berbasis pangan lokal(Aboul-Enein et al., 2016).

Buah pisang kepok merupakan buah tropis yang menjadi komoditas holtikultultura yang mudah dibudidayakan dan memiliki nilai produksi yang tinggi di Indonesia dengan kandungan gizi yang cukup baik terutama sebagai sumber serat dan kalium. Mineral lain yang terdapat dalam buah pisang antara lain magnesium, fosfor, besi dan sejumlah kalsium. Selain mineral, buah pisang juga mengandung beberapa jenis yaitu vitamin C, B kompleks dan serotonin yang berfungsi sebagai neurotransmiter(Ambarita et al., 2016). Tingkat kosumsi buah pisang kepok di Indonesia cukup tinggi yang artinya akan menghasilkan limbah kulit pisang yang banyak, namun masih kurang diminati oleh pelaku industri, sehingga mengakibatkan penumpukan yang tidak sedikit jumlahnya. Padahal jika dimanfaatkan dengan baik limbah kulit pisang akan memiliki nilai jual yang cukup tinggi, namun pada umumnya kulit pisang hanya dimanfaatkan sebagai pakan ternak atau pupuk organik saja. Kulit pisang dapat dimanfaatkan sebagai salah satu bahan pangan yang cukup tinggi nilai jualnya, selain untuk mengurangi banyaknya jumlah limbah kulit pisang kulit pisang juga memiliki kandungan zat gizi yang dapat dimanfaatkan oleh manusia antara lain kulit pisang mengandung 18,90 g karbohidrat pada setiap 100 gram(Yuliana, 2016).

Tepung kulit pisang kepok adalah tepung yang bahan utama pembuatannya menggunakan limbah dari buah pisang kepok. Menurut Tyaningsih(Dewi, 2014), kulit pisang dapat dijadikan tepung. Hal ini dibuktikan dengan penelitiannya tentang pemanfaatan limbah kulit pisang sebagai tepung terigu dalam pembuatan mie. Hasil analisisnya terbukti bahwa pati limbah kulit pisang dapat digunakan sebagai bahan tepung terigu dalam pembuatan mie dengan konsentrasi sebesar 20\%. Apabila persentase kulit pisang diatas $30 \%$ akan menghasilkan rasa yang getir atau pahit. Kulit pisang yang belum matang mengandung glikosida, flavonoid (leucocyanidin), tannin, saponin, dan steroid yang lebih tinggi dari pada yang sudah matang. Pada umumnya, olahan tepung kulit pisang kepok dijadikan produk pangan, seperti Biskuit, Wafer dan Es Krim.

Penambahan tepung kulit pisang pada pengolahan Biskuit akan menambah nilai gizi dan kualitas produk makanan, serta dapat dijadikan sebagai alternatif obat nonfarmoklogi untuk bebabagai penyakit seperti penyakit konstipasi dan hipertensi. Kandungan mineral serat dan kalium yang tinggi pada tepung kulit pisang kepok berpotensi dalam mencegah penyakit degeneratif tersebut. Amran(Amran et al., 2010), dkk tahun 2010 melakukan kajian terkait pengaruh tambahan asupan kalium terhadap penurunan hipertensi pada lansia yang memperlihatkan terjadi penurunan tekanan darah sistolik lansia setelah diberikan intervensi yaitu memberikan asupan kalium pada menu makanannya. Kandungan serat yang tinggi pada tepung kulit pisang akan mempengaruhi tekstur biskuit. Semakin tinggi kandungan serat pada maka semakin baik untuk pencernaan, sehingga biskuit tersebut juga dapat dijadikan alternatif makanan untuk diet.

Berdasarkan observasi awal yang telah dilakukan diketahui bahwa masyarakat Komplek POLRI Jatirangga, Bekasi memiliki daya konsumsi pisang yang cukup tinggi, dimana rata-rata 8 dari 10 keluarga menjadikan pisang sebagai buah yang paling sering dikonsumsi, baik untuk dimakan secara langsung ataupun dijadikan sebagai olahan lain seperti gorengan. Sebagian besar ibu-ibu di komplek tersebut tidak memiliki aktivitas khusus sehingga kegiatan ini akan mampu mendorong kreativitas masyarakat komplek dalam berwirausaha mandiri atau kelompok serta mengisi waktu luang dengan kegiatan yang bermanfaat. Pelaksanan kegiatan pengabdian kepada masyarakat ini bertujuan untuk memberdayakan masyarakat Komplek POLRI Jatirangga, Bekasi khususnya ibu-ibu rumah tangga dalam memanfaatkan limbah rumah tangga kulit Pisang Kepok (Musa paradisiaca L.) menjadi olahan biskuit yang bernilai gizi tinggi.

\section{METODE}

Pengambilan data pada pelaksanaan pengabdian kepada masyarakat ini dilakukan pada tanggal 5 April 2020 di Komplek POLRI Jatirangga, Bekasi dengan menggunakan metode penyuluhan yang terdiri dari 15 orang peserta. Seluruh peserta adalah ibu rumah tangga yang tidak memiliki aktivitas khusus. Kegiatan pengabdian kepada masyarakat ini 
diawali dengan paparan informasi pada masyarakat tentang manfaat tepung kulit pisang, kemudian dilanjutkan dengan sesi tanya jawab. Peserta penyuluhan juga diberikan leaflet sebelum acara sehingga mereka bisa membaca dan mempelajari terlebih dahulu tentang materi yang akan disampaikan. Proses ini akan memudahkan tanya jawab, sehingga diskusi menjadi lebih aktif. Setelah sesi diskusi selesai, dilanjutkan dengan demo masak. Kegiatan pengabdian kepada masyarakat melalui beberapa tahapan, yaitu :

\section{Persiapan Pembuatan Biskuit Tepung Kulit Pisang Kepok 1) Persiapan Bahan}

Sebanyak 1 kilo buah pisang, dicuci bersih lalu setelah dicuci bersih diambil kulit nya diiris tipis dan dipotong dengan ukuran kecil, kemudian direndam dengan larutan sodium bisulfat selama 15 menit agar tidak mudah teroksidasi, lalu ditiriskan dan di angin-anginkan setelah itu dikeringkan dengan menggunakan oven listrik dengan suhu $60^{\circ} \mathrm{C}$ selama 9 jam. Setelah kering, kulit pisang digiling menggunakan blender, lalu diayak untuk memisahkan bagian kasar dengan bagian halus. Tepung yang sudah halus disimpan dalam wadah kedap udara.

\section{2) Analisis proksimat tepung kulit pisang kepok}

Uji proksimat dilakukan untuk mengetahui karakteristik kimia dari tepung kulit pisang kepok. Analisis proksimat meliputi analisis kandungan karbohidrat, lemak, protein, jumlah energi, kadar air, kadar abu, sukrosa, analisis serat dan kadar kalsium.

\section{3) Pembuatan biskuit tepung kulit pisang kepok}

Telur dan gula dikocok sampai mengembang lalu ditambahkan mentega, butter dan baking powder lalu diaduk hingga merata sampai berwarna pucat,kemudian ditambahkan tepung terigu dan tepung kulit pisang kepok dengan perbandingan 50\%:50\%, ditambahkan sedikit susu bubuk aduk hingga tercampur rata, kemudian dicetak dan dipanggang dalam oven dengan $130^{\circ} \mathrm{C}$ selama 35 menit(Oktaviana et al., 2017).

\section{HASIL DAN PEMBAHASAN}

Tepung dari kulit pisang kepok digunakan akan mengurangi jumlah tepung terigu yang biasa dipakai dalam pembuatan biskuit dan berpotensi dalam mencegah penyakit degeneratif. Sebagian besar bahan utama pembuatan biskuit adalah tepung terigu yang pada umumnya mengandung zat gizi makro saja serta rendah serat. Menurut Djunaedi(Djunaedi, 2006), tepung kulit pisang memiliki kadar abu yang sesuai dengan kadar abu tepung terigu untuk bahan makanan yang disyaratkan oleh SNI 01-3751-1995 yaitu maksimal 0,7 \%. Tepung kulit pisang kepok memiliki kandungan zat besi sebasar 52,89 ppm dan memenuhi standar minimal kandungan zat besi yang ditetapkan oleh SNI tepung terigu 01-3751-2011 yaitu sebesar 50 $\mathrm{ppm}$ (mg/kg)(Indonesia \& Nasional, 2011). Maka dari itu jika dilihat dari beberapa kandungannya, tepung kulit pisang kepok dapat digunakan sebagai bahan alternatif pembuatan makanan khususya biskuit yang bisa meminimalisirkan penggunaan tepung terigu, namun dengan komposisi gizi yang sangat baik untuk kebutuhan tubuh.

Tepung kulit pisang yang sudah dianalisis kandungan proksimat didapatkan hasilnya sebagai berikut :

Tabel 1. Hasil Analisis Proksimat Tepung Kulit Pisang Kepok

\begin{tabular}{lccc}
\hline \multicolumn{1}{c}{ Komponen } & $\begin{array}{c}\text { Formula } \\
\text { Kontrol } \\
(\mathbf{F 0})\end{array}$ & $\begin{array}{c}\text { Formula } \\
\text { Terpilih } \\
(\mathbf{F 3})\end{array}$ & $\begin{array}{c}\boldsymbol{p} \text { - } \\
\text { value }\end{array}$ \\
\hline Karbohidrat (\%) & 62,65 & 62,91 & $0,000^{*}$ \\
Lemak (\%) & 12,51 & 12,23 & $0,000^{*}$ \\
Protein (\%) & 7,08 & 7,26 & $0,000^{*}$ \\
Serat Pangan (\%) & 51,93 & 51,21 & $0,000^{*}$ \\
Kalium (mg/100 g) & 3302,68 & 3272,69 & $0,000^{*}$ \\
Energi (kkal/100 g) & 391,51 & 390,75 & $0,000^{*}$ \\
Kadar Air (\%) & 8,91 & 8,82 & $0,000^{*}$ \\
Kadar Abu (\%) & 8,85 & 8,78 & $0,000^{*}$ \\
Sakarosa (\%) & Tidak & Tidak & $0,000^{*}$ \\
\hline
\end{tabular}

Keterangan: *)perbedaan secara signifikan $(p<0,05)$

Berdasarkan Tabel 1 di atas, didapatkan hasil Karbohidrat sebanyak 62,91\% yang tidak jauh beda dengan Standar Nasional Indonesia (01-2973-2011) kandungan karbohidrat pada biskuit minimal $70 \%$, artinya dengan penambahan sedikit tepung terigu makan akan memenuhi standar yang ditetapkan. Kandugan lemaknya sebanyak $12,23 \%$ yang berada diatas SNI biskut minimal sebesal $9,5 \%$. Protein yang terkandung sebanyak $7,26 \%$, Serat Pangan sebanyak $51,21 \%$, Kalium sebanyak $3272,69 \mathrm{mg} / 100 \mathrm{~g}$, Energi sebanyak 390,75 kkal/100 g, Kadar Air sebanyak 8,82 \% dan Kadar Abu sebanyak $8,78 \%$.

Kegiatan yang dilakukan pada pelaksanaan pengabdian kepada masyarakat ini adalah mengolah tepung kulit pisang yang sudah dianalisis kandungan proksimatnya untuk dijadikan biskuit. Pembuatan biskuit dipilih berdasarkan hasil observasi awal yang telah dilakukan dan dapat disimpulkan bahwa sebagian masyarakat Indonesia, termasuk warga Komplek Polri Jatirangga menyukai biskuit yang bisa dijadikan cemilan di pagi ataupun di sore hari. Selain itu juga proses 
pembuatannya cukup mudah dan dapat diaplikasikan oleh masyarakat. Disamping manfaat kesehatan yang akan diperoleh, produk ini juga dapat dikomersialisasikan sehingga masyarakat yang mengembangkan produk ini bisa mendapatkan keuntungan secara ekonomi.

Setelah selesai demo masak yang melibatkan perwakilan peserta, kami memberikan contoh makanan yang telah diolah pada peserta untuk dicicipi. Proses ini dilakuakna dengan tujuan agar mereka mengetahui bahwa rasa dari makanan olahan yang berbasis tepung kulit pisang tersebut memiliki rasa yang enak dan dapat diterima. Berdasarkan hasil uji organoleptik yang telah dikakukan, mayoritas responden memberikan nilai diatas 3 untuk semua atribut, hal ini menandakan bahwa peserta menyukai biskuit dari subsitusi tepung kulit pisang kepok seperti yang akan ditampilkan pada Gambar 1.

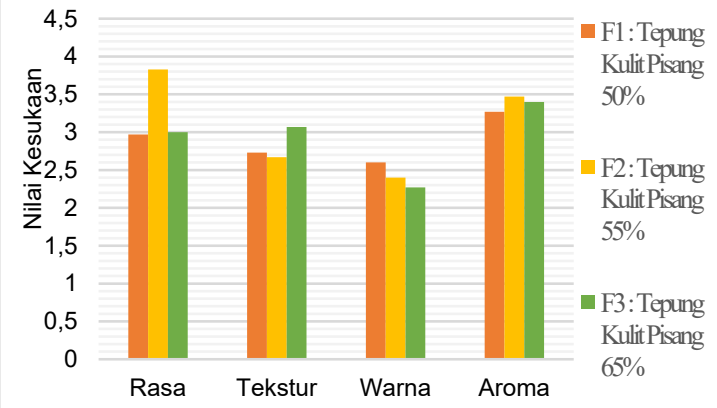

Gambar 1. Grafik Hasil Uji Hedonik Biskuit

Substitusi Tepung Kulit Pisang Kepok

Perbedaan tingkat kesukaan responden terhadap atribut tekstur produk biskuit disebabkan kandungan pektin pada kulit pisang yang mampu menghasilkan gel yang membantu meningkatkan tekstur sehingga dapat bermanfaat meningkatkan sensori pada produk pangan(Satria \& Ahda, 2011). Penambahan tepung terigu tetap dilakukan dikarenakan gluten yang dapat membentuk tekstur cookies hanya ada pada bahan terigu(Subandoro, 2014).

Berikut adalah hasil kegiatan yang dilakukan di Komplek Polri Jatirangga :

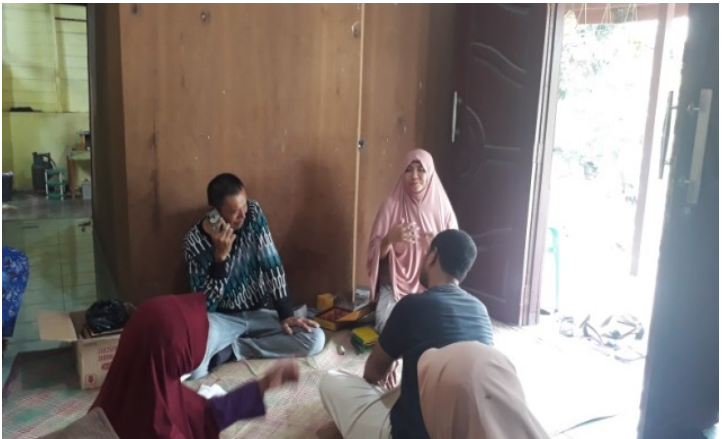

Gambar 2. Sosialisasi pemanfaatan dan pengolahan kulit pisang kepok

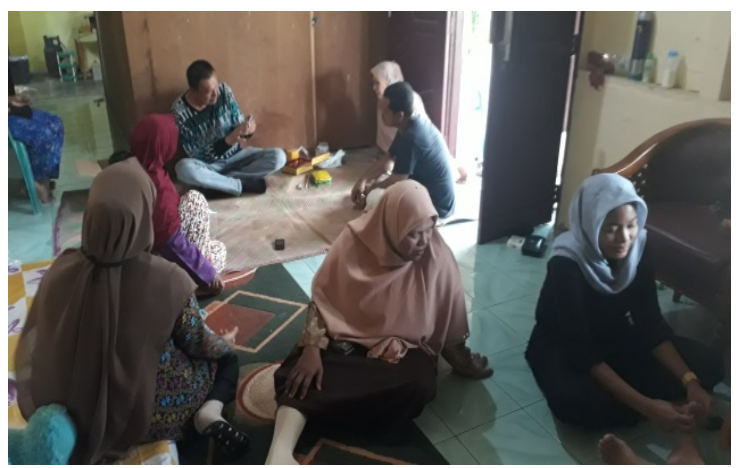

Gambar 3. Peserta saling berdiskusi terkait proses pembuatan tepung kulit pisang kepok

2. Persiapan bahan dan pengolahan kulit pisang kepok

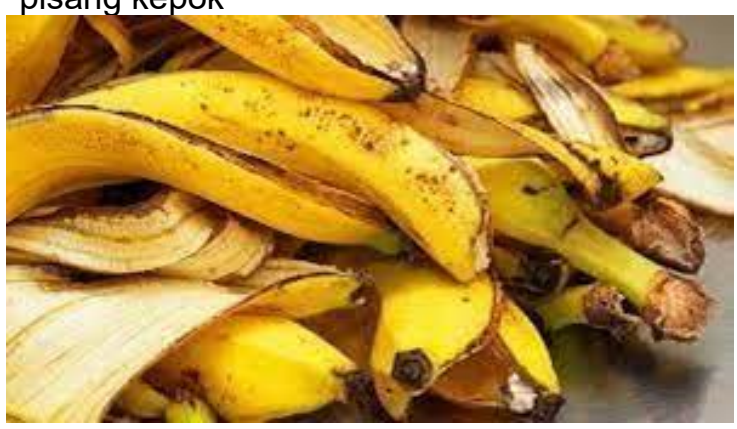

Gambar 4. Kulit Pisang Kepok

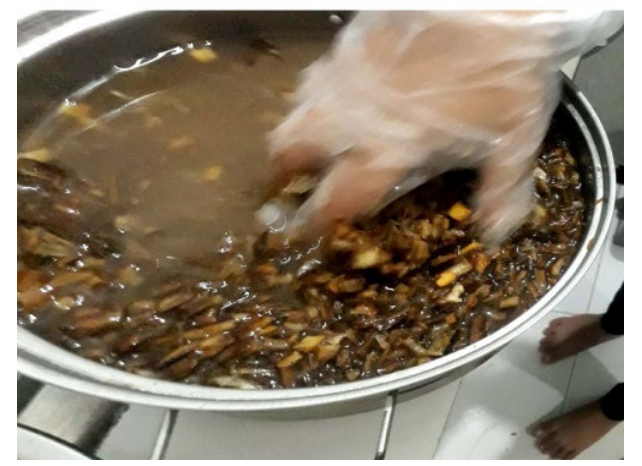

Gambar 5. Proses perendaman kulit pisang kepok dengan Sodium Bisulfat

1. Sosialisasi pemanfaatan dan pengolahan kulit pisang kepok 


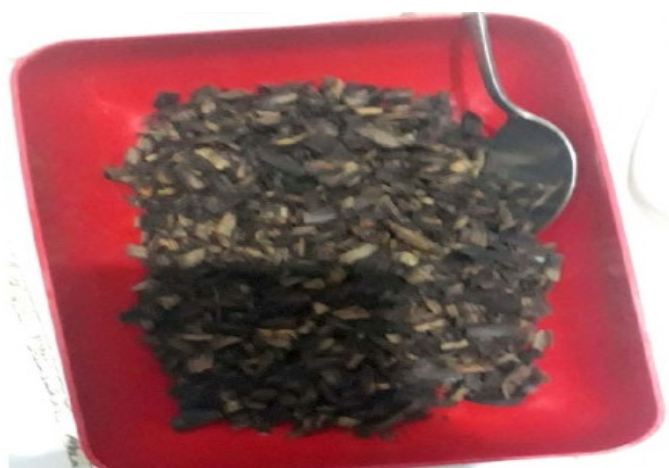

Gambar 6. Kulit Pisang kepok yang sudah dikeringkan dengan Oven

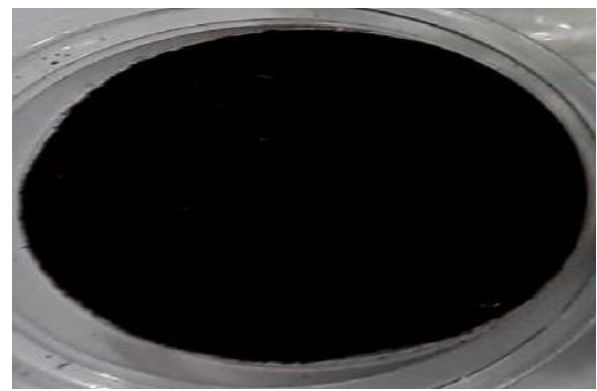

Gambar 7. Kulit pisang kepok yang sudah dihaluskan menjadi tepung

3. Pembuatan biskuit tepung kulit pisang kepok

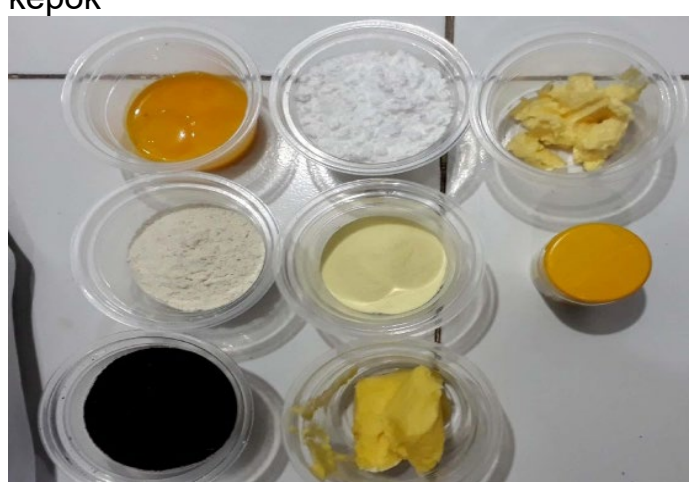

Gambar 8. Persiapan pembuatan biskuit tepung kulit pisang kepok

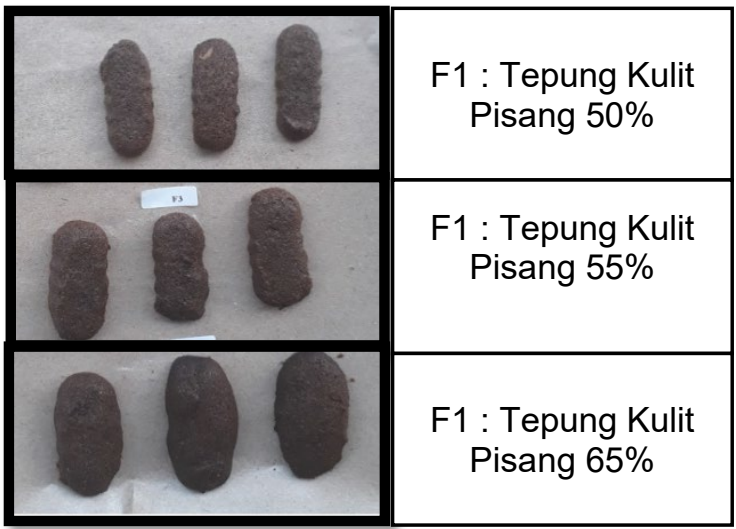

Gambar 9. Bentuk Biskuit tepung kulit pisang kepok yang sudah dioven

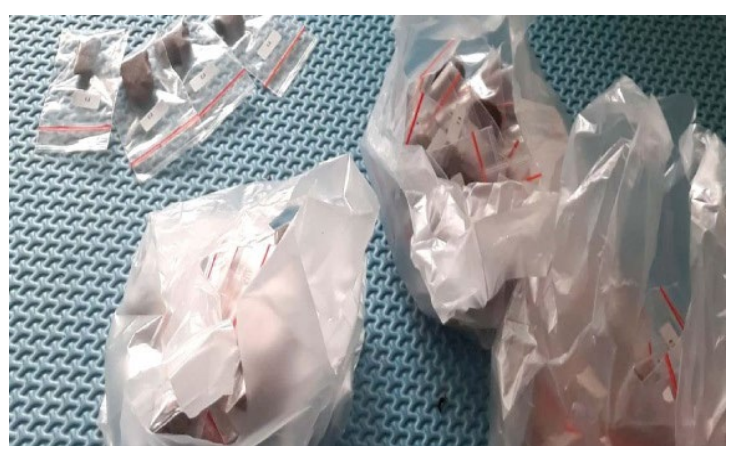

Gambar 10. Pengemasan Biskuit untuk dibawa pulang oleh peserta

\section{SIMPULAN DAN SARAN}

Daya terima produk biskuit dengan subsituli tepung kulit pisang kepok disukai oleh responden dan juga memiliki karakteristik kimia dengan kandungan kalori cukup tinggi sehingga memenuhi apabila digunakan sebagai makanan selingan untuk semua kalangan umur. Kegiatan Pengabdian Kepada Masyarakat ini yang dilakukan sangat bermanfaat karena masyarakat belum pernah mengolah kulit pisang kepok menjadi tepung yang bisa dimanfatkan menjadi berbagai macam olahan makanan yang berkhasiat tinggi .untuk tubuh, biasanya langsung dibuang setelah diambil buahnya. Adanya kegiatan ini masyarakat bisa mengkonversi salah satu limbah rumah tangga yaitu kulit pisang kepok sehingga memiliki nilai gizi dan nilai ekonomis. Biskuit ini berpotensi dalam mencegah penyakit degeneratif seperti penyakit konstipasi dan hipertensi karena kandungan mineral kalium dan serat pangan yang tinggi.

\section{UCAPAN TERIMAKASIH}

Terimakasih kepada semua pihak yang telah membantu pengabdian kepada masyarakat ini.

\section{DAFTAR RUJUKAN}

Aboul-Enein, A. M., Salama, Z. A., Gaafar, A. A., Aly, H. F., Bou-Elella, F. A., \& Ahmed, H. A. (2016). Identification of phenolic compounds from banana peel (Musa paradaisica L.) as antioxidant and antimicrobial agents. Journal of Chemical and Pharmaceutical Research, 8(4), 46-55.

Ambarita, M. D. Y., Bayu, E. S., \& Setiado, H. (2016). Identifikasi Karakter Morfologis Pisang (Musa Spp.) Di Kabupaten Deli Serdang. Jurnal Agroekoteknologi Universitas Sumatera Utara, 4(1), 1911-1924. https://doi.org/10.32734/jaet.v4i1.1240 4

Amran, Y., Febrianti, F., \& Irawanti, L. (2010). Pengaruh tambahan asupan kalium dari diet terhadap penurunan hipertensi 
sistolik tingkat sedang pada lanjut usia. Kesmas: Jurnal Kesehatan Masyarakat Nasional (National Public Health Journal), 5(3), 125-130.

Dewi, R. P. (2014). Pemanfaatan Kulit Pisang Ambon (Musa paradisiaca) sebagai Pektin Pada Selai Kacang Hijau (Phaseolus radiatus). Skripsi.

Djunaedi, E. (2006). Pemanfaatan Limbah Kulit Pisang Sebagai Sumber Pangan Alternatif dalam Pembuatan Cookies. Program Studi Kimia Fakultas Matematika Dan Ilmu Pengetahuan Alam Universitas Pakuan.

Indonesia, S. N., \& Nasional, B. S. (2011). Biskuit.

Oktaviana, A. S., Hersoelistyorini, W., \& Nurhidajah. (2017). Kadar Protein , Daya Kembang, dan Organoleptik Cookies dengan Substitusi Tepung Mocaf dan Tepung Pisang Kepok. Jurnal Pangan Dan Gizi, 7(2), 72-81.

Satria, B., \& Ahda, Y. (2011). Pengolahan Limbah Kulit Pisang Menjadi Pektin dengan Metode Ekstraksi. Jurnal Teknik Kimia, 024, 1-6.

Subandoro, A. (2014). The Cost of Scaling up Nutrition in Zambia: Executive Summary. World Bank, Washington DC Yuliana. (2016). Uji organoleptik dan kadar kalsium es krim dengan penambahan kulit pisang dan daun kelor sebagai sumber gizi alternatif. 1-11. 